BRITTO, Melina Carla de Souza; ERZINGER, Fernanda Huss; BARBOSA, Claudia Maria. O diálogo entre poderes e o reequilíbrio institucional: a (in)eficiência do diálogo no combate ao empoderamento judicial. Revista Eletrônica Direito e Política, Programa de Pós-Graduação Stricto Sensu em Ciência Jurídica da UNIVALI, Itajaí, v.16, n.2, $2^{\circ}$ quadrimestre de 2021. Disponível em: www.univali.br/direitoepolitica - ISSN 1980-7791.

\title{
O DIÁLOGO ENTRE PODERES E O REEQUILÍBRIO INSTITUCIONAL: A (IN)EFICIÊNCIA DO DIÁLOGO NO COMBATE AO EMPODERAMENTO JUDICIAL
}

\author{
THE DIALOGUE BETWEEN POWERS AND INSTITUTIONAL REBALANCING: THE \\ (IN)EFFICIENCY OF THE DIALOGUE IN COMBATING JUDICIAL EMPOWERMENT
}

\author{
Melina Carla de Souza Britto ${ }^{1}$ \\ Fernanda Huss Erzinger ${ }^{2}$ \\ Claudia Maria Barbosa ${ }^{3}$
}

\section{RESUMO}

Investiga-se a interação dialógica entre Legislativo e Judiciário e se tal diálogo pode ser um instrumento para combater o empoderamento judicial ou se acaba servindo de disfarce para o exercício do poder decisório sobre questões políticas, sociais e econômicas pelo Judiciário. Indaga-se se o diálogo institucional conseguiria romper a supremacia estabelecida pelo Judiciário. Averígua-se se o diálogo, por si só, é capaz de restabelecer o equilíbrio necessário entre o Legislativo e o Judiciário. O que se constata, por intermédio do método dedutivo de análise e de um estudo de revisão bibliográfica é que podem existir argumentos a favor e contrários ao diálogo institucional e que ele pode servir para combater a supremacia judicial e o sufocamento dos demais poderes. Percebe-se que o que Ihe falta é a eficiência no diálogo aberto e entre iguais, bem como a participação popular, prezando pelo prevalecimento da democracia e do constitucionalismo.

PALAVRAS-CHAVE: Separação de poderes, Poder Judiciário, reequilíbrio institucional, diálogo institucional.

\footnotetext{
ABSTRACT

The object of investigation in the dialogical interaction between Legislative and Judiciary Powers and if such dialogue can be an instrument to combat judicial empowerment or if it ends up serving as a disguise for the exercise of decisionmaking power over political, social and economic issues by the Judiciary. The

1 Programa de Pós-Graduação em Direito da Pontifícia Universidade Católica do Paraná, Curitiba, Paraná, Brasil. Mestra em Direito. E-mail: melina.britto@pucpr.edu.br.

2 Programa de Pós-Graduação em Direito da Pontifícia Universidade Católica do Paraná, Curitiba, Paraná, Brasil. Mestra em Direito. E-mail: fernandahuss@hotmail.com.

3 Programa de Pós-Graduação em Direito da Pontifícia Universidade Católica do Paraná, Curitiba, Paraná, Brasil. Doutora em Direito pela Universidade Federal de Santa Catarina. Professora titular da Pontifícia Universidade Católica do Paraná. E-mail: claudia.mr.barbosa@gmail.com.
} 
BRITTO, Melina Carla de Souza; ERZINGER, Fernanda Huss; BARBOSA, Claudia Maria. O diálogo entre poderes e o reequilíbrio institucional: a (in)eficiência do diálogo no combate ao empoderamento judicial. Revista Eletrônica Direito e Política, Programa de Pós-Graduação Stricto Sensu em Ciência Jurídica da UNIVALI, Itajaí, v.16, n.2, $2^{\circ}$ quadrimestre de 2021. Disponível em: www.univali.br/direitoepolitica - ISSN 1980-7791.

question is whether institutional dialogue could break the supremacy established by the Judiciary. It is examined whether that dialogue alone can restore the necessary balance between those two powers. Through an deductive method of analysis and an literature review study it is verified that there may be arguments for and against institutional dialogue and that, in short, it can serve to combat judicial supremacy and the suffocation of other powers. However, it is clear that what is lacking is efficiency in open and equal dialogue, as well as popular participation, prizing the prevalence of democracy and constitutionalism.

Keywords: Separation of powers, Judiciary, institutional rebalancing, institutional dialogue.

\section{INTRODUÇÃo}

A notória expansão do Poder Judiciário, perceptível no Brasil e em diversos outros países, de diferentes tradições jurídicas, como, por exemplo, Estados Unidos,, Canadá, Israel, Nova Zelândia, África do Sul, Colômbia, vem impondo uma revisão da separação de poderes e a noção de neutralidade propugnada por Montesquieu acerca do papel do Judiciário no Estado moderno. O Poder Judiciário nessas duas últimas décadas vem paulatinamente abandonando seu tradicional papel "silencioso" e neutro, para protagonizar o debate e a decisão política em torno de questões eram debatidas e resolvidas na esfera pública.

Face ao empoderamento judicial diversas teorias vêm procurando reequilibrar o funcionamento dos três Poderes de Estado, entre elas a teoria dos diálogos institucionais. O presente trabalho expõe as bases da teoria dos diálogos e a viabilidade de uma interação dialógica entre Legislativo e Judiciário, para combater o empoderamento judicial.

Para tanto, estuda-se a teoria da separação de poderes; o sistema de freios e contrapesos e sua aplicação nos dias atuais; o significado e a problematização acerca do empoderamento judicial; e a teoria do diálogo institucional como meio de interação entre os poderes estatais, em especial, o Legislativo e o Judiciário. Traz-se, ainda, o exemplo da PEC 33/2011 como uma tentativa (falha) de diálogo institucional no Brasil. 
BRITTO, Melina Carla de Souza; ERZINGER, Fernanda Huss; BARBOSA, Claudia Maria. O diálogo entre poderes e o reequilíbrio institucional: a (in)eficiência do diálogo no combate ao empoderamento judicial. Revista Eletrônica Direito e Política, Programa de Pós-Graduação Stricto Sensu em Ciência Jurídica da UNIVALI, Itajaí, v.16, n.2, $2^{\circ}$ quadrimestre de 2021. Disponível em: www.univali.br/direitoepolitica - ISSN 1980-7791.

Utilizando-se do método dedutivo de análise e de um estudo de revisão bibliográfica teórica e qualitativa, conclui-se que, apesar da interação dialógica entre Poder Judiciário e Poder Legislativo ser apontada como um caminho importante para a implementação de uma forma alternativa e cooperativa da interpretação constitucional, esse encadeamento não fornece, necessariamente, uma solução efetiva ao empoderamento judicial. Alguns autores afirmam, inclusive, que o diálogo pode servir para alavancar ainda mais a expansão do poder judicial, bem como asseveram que, não obstante o diálogo busque reestabelecer o essencial equilíbrio na relação existente entre os poderes, falta-lhe eficiência e eefetiva participação popular.

Em especial, no cenário brasileiro a adoção dessa construção de decisão coletiva entre Corte e Parlamento torna-se bastante dificultosa de modo que, ao invés do restabelecimento do equilíbrio necessário entre poderes, acaba servindo como uma forma de disputa por controle entre as instituições.

\section{A CLÁSSICA SEPARAÇÃo DE PODERES E O SISTEMA DE FREIOS E CONTRAPESOS}

A teoria da separação dos poderes tem antecedentes em Aristóteles, mas no seu formato clássico é atribuída à Montesquieu. No livro XI de sua obra "O Espírito das Leis", o francês preocupou-se em estabelecer uma divisão de funções e um eficiente sistema de limitações dos poderes do Estado liberal que emergia na Europa em resposta à queda do Estado Absolutista, pois, caso contrário, haveria o risco de uma tirania e "tudo estaria perdido se o mesmo homem, ou o mesmo corpo dos principais, ou dos nobres, ou do povo exercesse os três poderes: o de fazer as leis, o de executar as resoluções públicas e o de julgar os crimes ou as querelas entre os particulares". ${ }^{4}$

\footnotetext{
4 MONTESQUIEU. O Espírito das Leis. $6^{a}$ ed. Tradução de Pedro Vieira Mota. São Paulo: Saraiva, 1999. Disponível em: <http://egov.ufsc.br/portal/conteudo/o-esp\%C3\%ADrito-das-leis>. Acesso em: 11 jul. 2018. p. 75.
} 
BRITTO, Melina Carla de Souza; ERZINGER, Fernanda Huss; BARBOSA, Claudia Maria. O diálogo entre poderes e o reequilíbrio institucional: a (in)eficiência do diálogo no combate ao empoderamento judicial. Revista Eletrônica Direito e Política, Programa de Pós-Graduação Stricto Sensu em Ciência Jurídica da UNIVALI, Itajaí, v.16, n.2, $2^{\circ}$ quadrimestre de 2021. Disponível em: www.univali.br/direitoepolitica - ISSN 1980-7791.

A liberdade política seria encontrada, então, a partir de um Legislativo, um Executivo e um Judiciário independentes entre si, com funções diversas e específicas exercidas por órgãos próprios, interligados de maneira harmônica para a obtenção dos objetivos do governo, mantendo, no entanto, as características de cada poder de ser uno, indivisível e indelegável. Desta forma, uma atuação proporcional e coerente possibilitaria a desconcentração das atribuições estatais, evitando o abuso de poder por meio de um equilíbrio que a teoria política acabou consagrando como a doutrina dos checks and balances - freios e contrapesos.

No entanto, além das funções específicas de cada um, Montesquieu admitiu em tais poderes a necessidade de estatuir e de impedir. Assim, vê-se que quando foi analisada por ele, a teoria da separação dos poderes tinha o objetivo de assegurar a liberdade dos indivíduos. A divisão dos poderes do Estado contribuía no fortalecimento das garantias individuais de liberdade, pois objetivava enfraquecer a tirania e o poder do Estado, cabendo a este último apenas conservar as situações estabelecidas pelos indivíduos. ${ }^{5} \mathrm{O}$ ideal de liberdade assumiu suas principais feições na separação dos poderes, sendo incorporado às bases nascentes da organização constitucional do Estado Moderno.

James Madison, um dos colaboradores na formulação da Constituição norteamericana, escreveu em "O Federalista", capítulo 47, que "a acumulação dos poderes Legislativo, Executivo e Judiciário nas mãos de um só indivíduo, ou de uma só corporação, seja por efeito de conquista ou de eleição, constitui necessariamente a tirania". ${ }^{6}$ Assim, o esquema do equilíbrio entre os poderes, uma proposta do liberalismo da época, o qual era contra tanto ao conservadorismo favorável à concentração de poder quanto aos excessos do republicanismo, tinha como lema principal evitar os males graves que associava às concepções rivais: tirania e anarquia. ${ }^{7}$

\footnotetext{
${ }^{5}$ MONTESQUIEU. O Espírito das Leis. p. 77.

6 MADISON, James. Exame e explicação do princípio da separação dos poderes. In: HAMILTON, Alexander; JAY, John; MADISON, James. O Federalista. Trad. de Hiltomar Martins Oliveira. Belo Horizonte: Líder, 2003. p. 298.

7 GARGARELLA, Roberto. El nuevo constitucionalismo dialógico frente al sistema de los frenos y contrapesos. In: GARGARELLA, Roberto (Comp.). Por una justicia dialógica: El Poder Judicial como promotor de la deliberación democrática. $1^{\text {a }}$ ed. Buenos Aires: Siglo Veintiuno Editores, 2014.
} 
BRITTO, Melina Carla de Souza; ERZINGER, Fernanda Huss; BARBOSA, Claudia Maria. O diálogo entre poderes e o reequilíbrio institucional: a (in)eficiência do diálogo no combate ao empoderamento judicial. Revista Eletrônica Direito e Política, Programa de Pós-Graduação Stricto Sensu em Ciência Jurídica da UNIVALI, Itajaí, v.16, n.2, $2^{\circ}$ quadrimestre de 2021. Disponível em: www.univali.br/direitoepolitica - ISSN 1980-7791.

O constitucionalismo moderno fortalece-se no seio da teoria da separação de poderes e é tido como um pressuposto do Estado Democrático, uma vez que, respeitados as funções típicas de cada poder, haveria ainda mecanismos de controle e fiscalização mútua que assegurariam a harmonia na relação entre os poderes de Estado. Na arquitetura preconizada por Montesquieu, os atos praticados pelo Estado poderiam ser gerais, ou seja, aqueles praticados somente pelo Poder Legislativo, e especiais, atinentes ao Poder Executivo, que só atuaria depois de emitida a norma geral. O Poder Judiciário, por sua vez, seria o responsável pela função fiscalizadora, atuando sempre que houvesse exorbitância de qualquer dos poderes.

No final do século XIX, a partir da crise do Estado Liberal, percebem-se novas exigências. O Estado, até então abstencionista, passou a ser cada vez mais solicitado a agir, sobretudo para assegurar direitos típicos de um Estado Providência. Nesse contexto, a clássica separação dos poderes assume nova roupagem, com o Executivo à frente de iniciativas que antes estavam restritas ao Legislativo. A liberdade e proteção do indivíduo frente a eventuais abusos ou intervenção indevida do estado mantém-se.

Constata-se então a ampliação da esfera estatal, intensificando a influência do Estado em diversos setores da sociedade, o que inviabiliza, mesmo como modelo, a rigidez da teoria da separação de poderes, a qual cede aos poucos espaço para uma relação de interdependência e harmonia entre os poderes. Assim, manifestaram-se novas formas de relacionamento entre os órgãos Legislativo, Executivo e Judiciário, os quais devem ponderar pelo "princípio da harmonia", "que não significa nem o domínio de um pelo outro nem a usurpação de atribuições, mas a verificação de que, entre eles, há de haver consciente colaboração e controle recíproco, para evitar distorções e desmandos". 8

Para Maurilio Casas Maia a teoria da separação de poderes é um dos grandes dogmas do constitucionalismo moderno e atual. Segundo ele, "o repúdio à

p. $133-134$.

${ }^{8}$ SILVA, José Afonso da. Curso de Direito Constitucional Positivo. São Paulo: Malheiros, 2005. p. 111 . 
BRITTO, Melina Carla de Souza; ERZINGER, Fernanda Huss; BARBOSA, Claudia Maria. O diálogo entre poderes e o reequilíbrio institucional: a (in)eficiência do diálogo no combate ao empoderamento judicial. Revista Eletrônica Direito e Política, Programa de Pós-Graduação Stricto Sensu em Ciência Jurídica da UNIVALI, Itajaí, v.16, n.2, $2^{\circ}$ quadrimestre de 2021. Disponível em: www.univali.br/direitoepolitica - ISSN 1980-7791.

concentração de poderes em um só órgão ou sujeito é ínsito à teoria da separação dos poderes, porquanto a sobredita concentração possa ensejar e facilitar o uso arbitrário do poder". ${ }^{9}$

Com essa adaptação, os poderes do Estado deixaram de ser interpretados como efetivamente separados e rigidamente especializados para serem compreendidos como distintos e coordenados. Ampliaram-se os conceitos e adaptaram-se à realidade sócio-política, surgindo a ideia de colaboração de poderes, gerando também uma autonomia organizacional em cada poder com a possibilidade de intercomunicação de funções, desempenhadas sistematicamente em cooperação mútua.

Nasce, assim, uma independência orgânica, prezando sempre pela harmonia entre os órgãos Legislativo, Executivo e Judiciário, especialmente nos sistemas presidencialistas. A independência e a divisão de funções entre os poderes não são absolutas. Nesse sentido, os poderes encontram previsão constitucional para participar das atribuições uns dos outros, desempenhando funções atípicas, a fim de que os problemas do Estado sejam brevemente resolvidos.

De antemão, a Constituição Federal brasileira de 1988 consagra em seu artigo 20 a independência e a harmonia entre os poderes. ${ }^{10}$ Quanto à independência, José Afonso da Silva entende pela desnecessidade de autorização ou confiança de outro poder para fins de investidura e permanência na função. Por outro lado, a harmonia aponta para duas características: cortesia de tratamento e respeito mútuo em relação às prerrogativas e faculdades entre os poderes. ${ }^{11}$

Para mais, cabe salientar que no Brasil a tripartição de poderes foi acolhida pela Carta Magna de 1988, sendo verdadeira cláusula pétrea para salvaguardar o cidadão de abusos no uso do poder.

\footnotetext{
9 MAIA, Maurilio Casas. A separação de poderes no Brasil hoje. Revista de Direito Constitucional e Internacional, v. 25, n. 104, p. 15-36, nov./dez. 2017. p. 15-36.

10 BRASIL. Constituição da República Federativa do Brasil, de 05 de outubro de 1988. Disponível em: <http://www.planalto.gov.br/ccivil_03/Constituicao/ConstituicaoCompilado.htm>. Acesso em: 29 ago. 2019.

${ }^{11}$ SILVA, José Afonso da. Comentário contextual à Constituição. $9^{a}$ ed. São Paulo: Malheiros, 2014. p. 46.
} 
BRITTO, Melina Carla de Souza; ERZINGER, Fernanda Huss; BARBOSA, Claudia Maria. O diálogo entre poderes e o reequilíbrio institucional: a (in)eficiência do diálogo no combate ao empoderamento judicial. Revista Eletrônica Direito e Política, Programa de Pós-Graduação Stricto Sensu em Ciência Jurídica da UNIVALI, Itajaí, v.16, n.2, $2^{\circ}$ quadrimestre de 2021. Disponível em: www.univali.br/direitoepolitica - ISSN 1980-7791.

Pode-se afirmar que uma das principais ferramentas para prevenir o abuso de poder por parte dos agentes públicos é a separação de poderes e funções, exercidos por diferentes ramos do governo, os quais controlam-se mutuamente (sistema de freios e contrapesos ou checks and balances system). Nesse sentido, o princípio da separação de poderes é um dos mais importantes da teoria constitucional, sendo essencial em uma democracia constitucional. Ele pressupõe a existência de um respeito mútuo, além de um equilíbrio que mantém a relação entre os poderes. Esse equilíbrio, contudo, encontra-se fragilizado na atualidade, verificando-se uma prevalência do Poder Judiciário frente aos outros dois, porquanto os juízes passaram a decidir questões diversificadas e complexas, fazendo prevalecer por vezes seus próprios entendimentos sobre normas definidas pelos demais poderes ou, ainda, sobre o significado e alcance de normas constitucionais.

\section{O EMPODERAMENTO RESULTANTE DO ATIVISMO JUDICIAL}

O caso Marbury v. Madison no ano de 1803 é tido como o precursor do judicial review nos Estados Unidos da América, já que a ali ficou estabelecida a possibilidade de que que decisões emanadas pelo Poder Legislativo poderiam ser submetidas ao controle jurisdicional.

Embora os países common law e civil law tenham recepcionado de forma diferente a separação de poderes, é possível afirmar-se que a tese da separação de poderes está umbilicalmente ligada à formação do Estado Liberal, cuja preocupação central era justamente garantir os direitos individuais frente aos abusos do Poder do Estado. ${ }^{12}$ Foi nessa direção que a Constituição republicana de 1891 estatuiu a supremacia da Constituição, acompanhada da possibilidade de exercício do controle difuso de constitucionalidade (art. 59 e 60). Depois, em 1934, previu-se a possibilidade do controle concentrado de constitucionalidade.

12 BARBOSA, Claudia Maria. Algunos aspectos de la independencia judicial en Brasil. In: Independencia judicial en América Latina: ¿De quien, para que, como¿. Bogota: Ilsa, 2004, p. 417-437. 
BRITTO, Melina Carla de Souza; ERZINGER, Fernanda Huss; BARBOSA, Claudia Maria. O diálogo entre poderes e o reequilíbrio institucional: a (in)eficiência do diálogo no combate ao empoderamento judicial. Revista Eletrônica Direito e Política, Programa de Pós-Graduação Stricto Sensu em Ciência Jurídica da UNIVALI, Itajaí, v.16, n.2, $2^{\circ}$ quadrimestre de 2021. Disponível em: www.univali.br/direitoepolitica - ISSN 1980-7791.

A Constituição de 88 não destoou dessa tendência, ao contrário, afirmou-a, mas o fez de forma a expandir o papel do Judiciário na definição do conteúdo da norma constitucional, ao permitir o controle difuso a qualquer órgão judicial, e a atribuir o controle concentrado ao STF, de maneira que a Corte Suprema passou a funcionar neste caso com o duplo papel de corte constitucional e e última instância recursal. ${ }^{13}$

A expansão do poder do Judiciário para definir o alcance e significado da norma encontrou ainda amparo em uma teoria constitucional que, diferente do positivismo, advoga a textura aberta da norma constitucional, o caráter principiológico de muitas de suas normas, a normatividade de normas antes tidas por programáticas, e o compromisso político de buscar a efetividade das normas constitucionais por quaisquer dos poderes da República.

A supremacia da norma constitucional historicamente afirmada no Brasil, contudo, não autoriza o Judiciário em geral, e o Supremo Tribunal Federal em especial, a atuar como detentor da última palavra acerca dos significados da Constituição, seja em decisões das quais não cabe outro recurso, seja em questões que demandam interpretação constitucional.

Nesse contexto, os magistrados passaram a decidir sobre questões complexas referentes à política, moral, filosofia, biologia e economia, abrindo espaço a um crescente ativismo judicial que resulta em um inédito protagonismo político do Poder Judiciário. Julgadores e tribunais passaram, assim, a delimitar e a decidir quais os rumos a sociedade deve tomar, de maneira que parte das atribuições dos demais poderes fosse transferida ao Judiciário, justamente em razão da inércia daqueles. ${ }^{14}$

Sobre essa expansão de poder do Judiciário, Leandro Alves de Oliveira menciona que ela "está jungida a uma efetiva participação extensiva e vigorosa do Judiciário na consolidação de valores e fins preconizados constitucionalmente". ${ }^{15}$ Tratando

13 BARBOSA, Claudia Maria. Algunos aspectos de la independencia judicial en Brasil. p. 422.

14 OLIVEIRA, Leonardo Alves de. Ativismo judicial: qual o limite do Poder Judiciário? Revista Bonijuris, v. 29, n. 641, p. 24-28, abr. 2017. p. 25.

${ }^{15}$ OLIVEIRA, Leonardo Alves de. Ativismo judicial: qual o limite do Poder Judiciário? p. 26. 
BRITTO, Melina Carla de Souza; ERZINGER, Fernanda Huss; BARBOSA, Claudia Maria. O diálogo entre poderes e o reequilíbrio institucional: a (in)eficiência do diálogo no combate ao empoderamento judicial. Revista Eletrônica Direito e Política, Programa de Pós-Graduação Stricto Sensu em Ciência Jurídica da UNIVALI, Itajaí, v.16, n.2, $2^{\circ}$ quadrimestre de 2021. Disponível em: www.univali.br/direitoepolitica - ISSN 1980-7791.

notadamente a respeito do que seria o ativismo judicial, o autor realça que ele é "uma interpretação proativa da Lex Fundamentalis que propicia uma releitura de seu real sentido, alcance e valores axiológicos, com o objetivo de permitir a prolação de decisões modernas, reformadoras/revolucionárias, progressistas e construtivas". ${ }^{16}$

Indaga-se, contudo, se o Poder Judiciário, especificamente em relação ao STF, teria realmente autonomia para tanto, já que não se pode, em um sistema democrático, privilegiar um poder em detrimento do outro. Desse modo, para que não interfira de forma tão expressiva na atividade dos demais poderes, há quem argumente ser necessário impor limites à sua atuação.

Ademais, por mais que o ordenamento jurídico brasileiro determine ao STF a guarda da Constituição, certa dúvida poderia surgir com relação à sua legitimidade, sobretudo pelo fato de que a Corte é composta por juízes não eleitos que, ao contrário dos integrantes do Executivo e do Legislativo, não detém a legitimação democrática.

No vértice oposto dos que advogam um olhar positivo ao ativismo, Alexandre Sturion de Paula considera o ativismo uma forma atípica e desenfreada de criação de normas pelos membros do Judiciário, na qual ele usurpa a função legítima conferida pela Carta Magna ao Legislativo, influindo também muitas vezes em competências próprias do Executivo, de organização econômico-financeira e políticas públicas. ${ }^{17}$

Outro argumento contrário ao ativismo diz respeito à segurança jurídica, de modo que, cada vez mais, não seria possível prever qual o posicionamento a ser adotado pelo julgador diante de um caso concreto, distanciando-se das disposições expressas da lei.

Nesse ponto de vista, face ao empoderamento judicial, o fundamento da soberania popular é abalado e o entrave à prática democrática é instaurado. O que é

\footnotetext{
16 OLIVEIRA, Leonardo Alves de. Ativismo judicial: qual o limite do Poder Judiciário? p. 26.

17 PAULA, Alexandre Sturion de. Ativismo judicial no processo civil: limites e possibilidades constitucionais. Campinas: Servanda, 2012. p. 147-155.
} 
BRITTO, Melina Carla de Souza; ERZINGER, Fernanda Huss; BARBOSA, Claudia Maria. O diálogo entre poderes e o reequilíbrio institucional: a (in)eficiência do diálogo no combate ao empoderamento judicial. Revista Eletrônica Direito e Política, Programa de Pós-Graduação Stricto Sensu em Ciência Jurídica da UNIVALI, Itajaí, v.16, n.2, $2^{\circ}$ quadrimestre de 2021. Disponível em: www.univali.br/direitoepolitica - ISSN 1980-7791.

realmente preocupante é que, se de um lado houve o crescimento das competências e funções do Poder Judiciário, com uma progressiva intervenção do STF no processo legislativo, de outro não ocorreu qualquer mudança para ampliar ou melhorar, na mesma proporção, os mecanismos de accountability da Corte constitucional. ${ }^{18}$

\section{LIMITES E POTENCIALIDADES DO DIÁLOGO INSTITUCIONAL}

A ideia de "diálogo institucional" teve origem no debate canadense acerca da legitimidade democrática do controle de constitucionalidade. Em suma, a perspectiva do diálogo entre os poderes surgiu com a finalidade de impedir a disseminação do ativismo judicial, moderando a atuação do Judiciário (minimalismo judicial), visando restaurar sua neutralidade.

Os canadenses Peter W. Hogg e Alisson A. Bushell debatem o diálogo institucional como uma forma de legitimação do controle de constitucionalidade. ${ }^{19} \mathrm{Em}$ suma, esses autores defensores do diálogo afirmam que decisões judiciais, boas ou ruins, raramente impedem que o Poder Legislativo se manifeste (seja concordando ou não, por exemplo, com a decisão judicial exarada), sendo necessária uma interação, um diálogo entre Judiciário e Parlamento, com o intuito de que se estabeleça a melhor interpretação constitucional que, mesmo quando provisória, possa funcionar como última palavra acerca dos significados da Constituição.

Nesse sentido Luc B. Tremblay explica que para aqueles que defendem o "diálogo institucional" como uma forma de legitimação do controle de constitucionalidade, o Poder Judiciário e o Poder Legislativo participariam de um diálogo, um debate, sobre a determinação do equilíbrio adequado entre os princípios constitucionais e as políticas públicas. Esse diálogo, explica o autor, seria permanente, uma vez que

\footnotetext{
${ }^{18}$ SILVA, Eduardo Fernandes da. Excesso de jurisdição ou escassez de política: apontamentos sobre a jurisdição constitucional brasileira à luz da evolução histórica do estado democrático de direito. Revista da Faculdade de Direito da UFMG, n. 62, p. 209-230, jan./jun. 2013. p. 226.

19 HOGG, Peter W.; BUSHELL, Allison A. El diálogo de la Carta entre los tribunales y las legislaturas. Revista Argentina de Teoría Jurídica, Universidad Torcuato di Tella, Escuela de Derecho, v. 14, p. 75-118, dez. 2013. Disponível em: $<$ https://www.utdt.edu/ver_contenido.php?id_contenido=9173\&id_item_menu=5858 $>$. Acesso em: 24 jun. 2018.
} 
BRITTO, Melina Carla de Souza; ERZINGER, Fernanda Huss; BARBOSA, Claudia Maria. O diálogo entre poderes e o reequilíbrio institucional: a (in)eficiência do diálogo no combate ao empoderamento judicial. Revista Eletrônica Direito e Política, Programa de Pós-Graduação Stricto Sensu em Ciência Jurídica da UNIVALI, Itajaí, v.16, n.2, $2^{\circ}$ quadrimestre de 2021. Disponível em: www.univali.br/direitoepolitica - ISSN 1980-7791.

o Judiciário não possuiria necessariamente a última palavra em relação a questões políticas-constitucionais e o Legislativo quase sempre disporia, então, do poder de reverter, modificar ou anular uma decisão judicial. ${ }^{20}$ Em outros palavras, o Poder Legislativo teria resguardada a possibilidade de reverter ou modificar uma decisão do Poder Judiciário, instituindo nova legislação que, no seu entendimento, expressasse uma finalidade política, social ou econômica em consonância com a vontade dos cidadãos, representados pelo Legislativo.

A posição dos autores canadenses reverbera na posição externada por Claudia de Oliveira Fonseca, a qual ressalta o papel de interação entre os Poderes Legislativo e Judiciário. Segundo ela, para se adotar a teoria do diálogo institucional, a Corte não seria a detentora da última palavra sobre as questões constitucionais, incorrendo, portanto, uma interação, com possibilidade de um consenso entre Legislativo e Judiciário na interpretação dos direitos previstos no texto constitucional. ${ }^{21}$

A adoção desse procedimento dialógico possibilitaria a superação do estigma de poder contramajoritário, atribuído ao Judiciário, pelo fato de seus membros não serem eleitos pelo voto popular, tal qual acontece com os membros do Legislativo, uma vez que as decisões seriam construídas em conjunto, por meio do consenso entre os poderes. Buscar-se-ia, portanto, por meio do equilíbrio entre os poderes estatais, afastar a ideia de que o Poder Judiciário, e, especialmente as Cortes

\footnotetext{
20 TREMBLAY, Luc B. The legitimacy of judicial review: the limits of dialogue between courts and legislatures. Oxford University Press and New York University School of Law, I-CON, v. 3, n. 4, p. 617-648, $2005 . \quad$ Disponível <https://watermark.silverchair.com/moi042.pdf?token=AQECAHi208BE49Ooan9kkhW_Ercy7Dm3Z L_9Cf3qfKAc485ysgAAAZ0wggGZBgkqhkiG9w0BBwagggGKMIIBhgIBADCCAX8GCSqGSİb3DQEHAT AeBglghkgBZQMEAS4wEQQM44sNxfQZjHhX2X3-

AgEQgIIBUEbEQBgLA74McXAeUIKLB0XmxcECrLfIBkYaponndRPhbP_GPWZDD3L8stKye5q1E5gTb2iXpkQILMTP8pTV7e-xaIxhFjPdtKflHiOd-

DPDr85mdYKnYgxfYILohXP74BgPQf7hpUWufNyqRndyf1sc_PuyRZxv7scIpe1AGF2i1Q42cHk2BXXnav TwzJHrRSoTEeqYOHQKWQJrmo7pECjf9oTtS8-mv22CtiM-s9NosYB0iJ7Ob8PIIr_SNTwzOMtePcoi1tN7QP98EGkg5SRZhxHv-

7ZqHGpT24MgRIfL8aqpdP4HNAJY8SCA1 yeoLx3Hqvc5TAePa6nHJlejkta7LrXflvYyW8EVBWf4LKFEdQz HIGPWwT9oNGVrQMYhMIsss]-hiMO5GAQ25kzBcR-

ON52rfXmCxhvCAfL3EsI4IQxmUcJqGYDnOP_OIMA>. Acesso em: 30 jul. 2018. p. 617-618.

${ }^{21}$ FONSECA, Claudia de Oliveira. O ativismo judicial e a supremacia legislativa no contexto dos diálogos institucionais. Caderno de Ciências Sociais Aplicadas, Vitória da Conquista, n. 15, p. 3557, jul./dez. 2013. p. 35-57.
} 
BRITTO, Melina Carla de Souza; ERZINGER, Fernanda Huss; BARBOSA, Claudia Maria. O diálogo entre poderes e o reequilíbrio institucional: a (in)eficiência do diálogo no combate ao empoderamento judicial. Revista Eletrônica Direito e Política, Programa de Pós-Graduação Stricto Sensu em Ciência Jurídica da UNIVALI, Itajaí, v.16, n.2, $2^{\circ}$ quadrimestre de 2021. Disponível em: www.univali.br/direitoepolitica - ISSN 1980-7791.

Constitucionais, a exemplo do STF no caso do Brasil, seria o poder mais apto para dar a "última resposta" diante de tensões que atinjam matérias constitucionais. ${ }^{22}$

Na lógica das propostas dialógicas, não há espaço para a competição ou o conflito entre poderes pela "última palavra", "[...] mas um diálogo permanente e cooperativo entre instituições, que, por meio de suas singulares expertises e contextos decisórios, são parceiros na busca do melhor significado constitucional". Logo, não haveria um monopólio da "última palavra" por qualquer dos poderes: a "separação de poderes, nesse sentido, envolveria circularidade e complementaridade infinitas". 23

A respeito dos benefícios do diálogo institucional, faz jus o apontamento de Juliano Zaiden Benvindo que, transcrevendo as ideias de Louis Fisher a respeito do diálogo constitucional e avaliando propostas teóricas do chamado constitucionalismo democrático, reconhece ser este "marcado por uma ampla integração entre os diferentes Poderes e, sobretudo, pelo reconhecimento do caráter nitidamente político de todos eles, respeitando-se, naturalmente, suas diversidades nesse aspecto". ${ }^{24}$ Nesse sentido, o diálogo poderia ser encarado como fruto da separação de poderes, onde o controle recíproco entre poderes, em conjunto com a supervisão popular sobre eles, possibilitaria incrementar a qualidade do processo de interpretação constitucional.

Ainda em defesa de teorias dialógicas, Jorge Munhós de Souza destaca a importância do trabalho de Luis Fisher e Neal Devins intiulado "Diálogo como fruto da separação de poderes". Nele os autores identificam algumas características comuns a essas teorias, tais como o questionamento da supremacia judicial, a recusa da existência da última palavra e a valorização do procedimento democrático, mas o fazem muito antes da emergência das discussões contemporâneas, pois que, conforme registra Souza, "Já na década de 80 Fisher

22 FONSECA, Claudia de Oliveira. O ativismo judicial e a supremacia legislativa no contexto dos diálogos institucionais. p. 35-57.

${ }^{23}$ SOUZA, Jorge Munhós de. Diálogo Institucional: em algum lugar entre as teorias da supremacia. In: FELLET, André Luiz Fernandes; NOVELINO, Marcelo; PAULA, Daniel Giotti de (Orgs.). As novas faces do ativismo judicial. $2^{a}$ ed. Bahia: Editora Juspodivm, 2013. p. 335.

${ }^{24}$ FISHER apud BENVINDO, Juliano Zaiden. A "última palavra", o poder e a história: O Supremo Tribunal Federal e o discurso de supremacia no constitucionalismo brasileiro. Revista de Informação Legislativa, ano 51, n. 201, p. 71-95, jan./mar. 2014. p. 73. 
BRITTO, Melina Carla de Souza; ERZINGER, Fernanda Huss; BARBOSA, Claudia Maria. O diálogo entre poderes e o reequilíbrio institucional: a (in)eficiência do diálogo no combate ao empoderamento judicial. Revista Eletrônica Direito e Política, Programa de Pós-Graduação Stricto Sensu em Ciência Jurídica da UNIVALI, Itajaí, v.16, n.2, $2^{\circ}$ quadrimestre de 2021. Disponível em: www.univali.br/direitoepolitica - ISSN 1980-7791.

defendia a ideia de que os princípios constitucionais emergiriam de um diálogo entre os três ramos do Estado e o público em geral, analisando, para tanto, uma série de circunstâncias colaterais que estavam envolvidas nas mais importantes e controvertidas decisões da Suprema Corte". ${ }^{25}$

Dessa forma, em substituição à supremacia judicial, haveria diálogo entre Legislativo, Judiciário e Executivo. Existiria um processo interativo envolvendo outros atores responsáveis por contribuir para a definição dos rumos políticos, sociais e econômicos do país.

Sobre a crítica à supremacia judicial, Souza adverte que para além do fato de não possuírem legitimação democrática, é preciso considerar também que os tribunais, ao decidirem, são influenciados pela opinião pública, pelas manifestações parlamentares e tendências do Poder Executivo, sendo suas decisões submetidas ao jogo político a fim de que sejam implementadas a contento. ${ }^{26}$

Destarte, se torna evidente, para aqueles que defendem a teoria dialógica, que a influência recíproca entre os poderes estatais, sublinhada pelo diálogo entre representantes eleitos, o público e os tribunais, incrementa a qualidade das decisões constitucionais e faz jus ao processo democrático.

Percebe-se, então, que para essa parte da doutrina, o diálogo é a solução encontrada para que haja uma interação menos conflituosa entre Poder Judiciário e Legislativo, prevalecendo o ideal democrático, visto que as decisões constitucionais devem ser produzidas por um processo de elaboração compartilhada entre o Poder Judiciário e outros atores constitucionais. ${ }^{27}$

Além disso, conforme visto acima, o diálogo é uma forma de qualificar as teorias da "última palavra" e defender a segmentação do poder. Rejeita-se, assim, a

\footnotetext{
${ }^{25}$ FISHER; DEVINS apud SOUZA, Jorge Munhós de. Diálogo Institucional: em algum lugar entre as teorias da supremacia. p. 339-340.

26 SOUZA, Jorge Munhós de. Diálogo Institucional: em algum lugar entre as teorias da supremacia. p. 339-340.

27 BATEUP, Christine A. The Dialogue Promise: Assessing the Normative Potential of Theories of Constitutional Dialogue. Brooklyn Law Review, v. 71, 2006. p. 1.
} 
BRITTO, Melina Carla de Souza; ERZINGER, Fernanda Huss; BARBOSA, Claudia Maria. O diálogo entre poderes e o reequilíbrio institucional: a (in)eficiência do diálogo no combate ao empoderamento judicial. Revista Eletrônica Direito e Política, Programa de Pós-Graduação Stricto Sensu em Ciência Jurídica da UNIVALI, Itajaí, v.16, n.2, $2^{\circ}$ quadrimestre de 2021. Disponível em: www.univali.br/direitoepolitica - ISSN 1980-7791.

supremacia de qualquer um dos poderes em razão da importância dada aos "valores da liberdade, do discurso, da deliberação e do governo limitado". ${ }^{28}$

Enquanto defensores da ideia dialógica advogam a potencialidade de os diálogos favorecerem um processo decisório mais democrático, mais participativo e menos "juristocrático"29, os céticos, mais próximos dos estudos da ciência política, focam os limites das teorias dialógicas em dificuldades institucionais.

Barbara Billingsley em Listening to the dialogue: an Examination of the Degree of Public and Media Attention Provided to the Legislative Responses to Court Decisions Involving Equality Rights and Sexual Orientation, adverte para o fato de que a legitimação do diálogo requer que o discurso entre tribunal e parlamento seja ouvido (compreendido) pelo povo. Em suas palavras, "o público tem ouvido as palavras dos tribunais, mas não tem ouvido as palavras correspondentes dos Legisladores". 30 Ainda, segundo a autora, "para que qualquer troca de ideias/diálogo entre o Poder Judiciário e o Poder Legislativo seja valiosa e para que o valor de tal troca seja razoavelmente avaliado pelo público, ambos os lados do intercâmbio devem ser relatados". ${ }^{31}$ Nesse sentido, "o público deve ser informado de qualquer diálogo que esteja ocorrendo entre os tribunais e o Legislativo".32

\section{Luc Tremblay aponta em seu trabalho The legitimacy of judicial review,} dificuldades em operacionalizar verdadeiros diálogos entre Legislativo e Judiciário, e daí a dificuldade de que mecanismos dialógicos possam ser utilizados para legitimar o controle de constitucionalidade.

\footnotetext{
${ }^{28}$ SOUZA, Jorge Munhós de. Diálogo Institucional: em algum lugar entre as teorias da supremacia. p. 341.

${ }^{29}$ Permitindo-se aqui a utilização do termo criado por Ran Hirschl, mas com a finalidade de qualificar - processo decisório sobre questões políticas, econômicas e sociais como pertencendo eminentemente ao Poder Judiciário.

30 BILLINGSLEY, Barbara. Listening to the Dialogue: An Examination of the Degree of Public and Media Attention Provided to the Legislative Responses to Court Decisions Involving Equality Rights and Sexual Orientation. Dialogues about Justice: The Public, Legislators, Courts and the Media. October, Hull, QC, 2002. Disponível em: <https://ciaj-icaj.ca/wpcontent/uploads/2016/05/billingsleybarb_27-60.pdf>. Acesso em: 13 jul. 2018. p. 56-57.

31 BILLINGSLEY, Barbara. Listening to the Dialogue: An Examination of the Degree of Public and Media Attention Provided to the Legislative Responses to Court Decisions Involving Equality Rights and Sexual Orientation. p. 56-57.

32 BILLINGSLEY, Barbara. Listening to the Dialogue: An Examination of the Degree of Public and Media Attention Provided to the Legislative Responses to Court Decisions Involving Equality Rights and Sexual Orientation. p. 56-57.
} 
BRITTO, Melina Carla de Souza; ERZINGER, Fernanda Huss; BARBOSA, Claudia Maria. O diálogo entre poderes e o reequilíbrio institucional: a (in)eficiência do diálogo no combate ao empoderamento judicial. Revista Eletrônica Direito e Política, Programa de Pós-Graduação Stricto Sensu em Ciência Jurídica da UNIVALI, Itajaí, v.16, n.2, $2^{\circ}$ quadrimestre de 2021. Disponível em: www.univali.br/direitoepolitica - ISSN 1980-7791.

Antes de discutir propriamente a possibilidade de o diálogo institucional ser a solução para a supremacia judicial, partindo da análise a respeito da validade do controle de constitucionalidade pelo Poder Judiciário, o autor destaca o problema de legitimidade desse último poder, o qual "está enraizado no pressuposto majoritário de que a fonte suprema de legislação legítima em uma democracia está na vontade da maioria do povo ou de seus representantes eleitos". Assim, presume-se que "a legislação promulgada de acordo com o governo da maioria pelo povo ou por seus representantes eleitos é, em princípio, democraticamente legítima". O óbice está justamente no fato de que o controle de constitucionalidade "envolve juízes que são capazes de anular a legislação democraticamente promulgada de acordo com a regra da maioria, e, no entanto, esses juízes não são o povo nem são eleitos por eles; eles não representam os cidadãos e nem são responsabilizados por suas decisões". ${ }^{33}$

Dessa feita, pode-se dizer que, mesmo que se defenda a ideia de diálogo entre poderes, a fim de legitimar o controle de constitucionalidade, tal como previa Peter W. Hogg e Alisson A. Bushell citados acima, a própria ideia de conceder ao Judiciário poder bastante para rever ou anular determinada lei é ilegítima frente ao processo democrático.

Para Jean Leclair, a desvantagem do diálogo estaria focada na qualidade da participação democrática. Em sua análise, o principal inconveniente é que o conceito de diálogo, na concepção usada pela doutrina e pela Suprema Corte canadense, está interligado às relações existentes (ou que deveriam existir) entre o Legislativo e o Judiciário na interpretação constitucional, deixando o cidadão como mero observador da vida política, ao invés de encorajar a sua participação ativa.

Percebendo a relação existente entre empoderamento judicial e perda da representatividade do povo nas decisões que mais afetam a sociedade, e assim, a quebra da ideia de equilíbrio na separação de poderes, o autor busca soluções para incentivar a participação popular no processo de governança. Em suma, para ele,

33 TREMBLAY, Luc B. The legitimacy of judicial review: the limits of dialogue between courts and legislatures. p. 619-620. 
BRITTO, Melina Carla de Souza; ERZINGER, Fernanda Huss; BARBOSA, Claudia Maria. O diálogo entre poderes e o reequilíbrio institucional: a (in)eficiência do diálogo no combate ao empoderamento judicial. Revista Eletrônica Direito e Política, Programa de Pós-Graduação Stricto Sensu em Ciência Jurídica da UNIVALI, Itajaí, v.16, n.2, $2^{\circ}$ quadrimestre de 2021. Disponível em: www.univali.br/direitoepolitica - ISSN 1980-7791.

o diálogo institucional, a fim de legitimar uma interpretação constitucional ampla pela Corte canadense, tem o efeito de esmorecer a participação dos cidadãos nos debates fundamentais que permeiam a sociedade. ${ }^{34}$

Desde um olhar externo ao Canadá, mas enfatizando a análise dos limites do ambiente institucional em que os diálogos se desenvolvem, é importante observar a análise do jurista argentino Roberto Garagarella. Em sua análise ele reconhece que para alguns autores um sistema estruturado e organizado com base no modelo de freios e contrapesos favorece o diálogo institucional. Com efeito, o fato do poder, nesse sistema, ser dividido e admitir decisões tomadas por diferentes ramos do governo, auxilia na regulação das iniciativas normativas, a fim de que sejam moderadas e enriquecidas com diversos pontos de vista. ${ }^{35}$ Sendo assim, o sistema de freios e contrapesos, em um primeiro momento, favoreceria a revisão na tomada de decisões e, seria, portanto, legitimadora do controle de constitucionalidade.

Entretanto, destaca que essa observação não leva em conta as limitações estruturais que obstaculizam o desenrolar do diálogo judicial. O problema se encontra no fato de que as medidas que visam o diálogo institucional estão enquadradas em uma estrutura antiga de freios e contrapesos e tendem a se malograr no decorrer do caminho. Permita-se a tradução livre de suas palavras: "elas permanecem como experiências mais ou menos isoladas, ocasionalmente promovidas por alguns funcionários (bem-intencionados ou dispostos a resolver um problema)"; ou "remetem a novas práticas institucionais interessantes, mas não podem ser claramente descritas como práticas de diálogo". ${ }^{36}$ Nesse sentido, o antigo modelo de freios e contrapesos não está adaptado às novas práticas institucionais.

\footnotetext{
${ }^{34}$ LECLAIR, Jean. La métaphore du dialogue en droit constitutionnel canadien: un concept qui dessert les intérêts du citoyen?. Dialogues about Justice: The Public, Legislators, Courts and the Media. October, Hull, QC, 2002. Disponível em: <https://ciaj-icaj.ca/wpcontent/uploads/documents/2016/09/625.pdf?id=7925\&1531924967>. Acesso em: 18 jul. 2018. p. 86-87.

35 GARGARELLA, Roberto. El nuevo constitucionalismo dialógico frente al sistema de los frenos y contrapesos. p. 137.

36 GARGARELLA, Roberto. El nuevo constitucionalismo dialógico frente al sistema de los frenos y contrapesos. p. 146.
} 
BRITTO, Melina Carla de Souza; ERZINGER, Fernanda Huss; BARBOSA, Claudia Maria. O diálogo entre poderes e o reequilíbrio institucional: a (in)eficiência do diálogo no combate ao empoderamento judicial. Revista Eletrônica Direito e Política, Programa de Pós-Graduação Stricto Sensu em Ciência Jurídica da UNIVALI, Itajaí, v.16, n.2, $2^{\circ}$ quadrimestre de 2021. Disponível em: www.univali.br/direitoepolitica - ISSN 1980-7791.

Considerados os prós e contras, não se pode descurar da advertência de Benvindo. Para ele o diálogo institucional pode ser visto como meio de intervencionismo judicial, servindo de tela para o ativismo judicial. Isto porque não resta claro que o diálogo seja, juntamente com o sistema de freios e contrapesos, realmente efetivo para combater o empoderamento judicial. Na competição por mais poder, o destaque é dado pelo autor ao Poder Judiciário, resguardando-se que "[...] por mais que se critique o avanço do Judiciário no âmbito de tais desacordos políticos, existe uma certa aceitação social desse seu novo papel ou mesmo que tais acordos, que deram ensejo a uma certa supremacia do Judiciário, são, em grande medida frutos de arranjos políticos para o próprio benefício dos políticos" ${ }^{37}$

Aliás, se bem observado o que defende Luc B. Tremblay, não existe realmente um diálogo entre poderes que legitime essa espécie de atuação "empoderada" do Judiciário, seja ele uma forma de diálogo como conversação, seja como deliberação. ${ }^{38,39}$ Veja-se que as resposta do Poder Legislativo ao controle de constitucionalidade exercido pelo Judiciário, podem ser encaradas como meras manifestações às impugnações legais ou emendas legislativas acatando as insurgências judiciais (uma mera aceitação/aquiescência), sem qualquer evidência da existência de um diálogo real e interativo entre iguais.

Da mesma maneira, não há que se falar que, tal como estabelecido na própria doutrina da separação de poderes e do sistema de freios em contrapesos, um dado poder tenha poder de "mando" sobre o outro. O que se aponta, portanto, é para o risco desse "pseudo-diálogo" resultar, na verdade, em um monólogo judicial, ou seja, em mais uma forma de supremacia judicial ou, de modo inverso, como previu Luc B. Tremblay, em uma supremacia legislativa se, por acaso, invertêssemos o poder da "última palavra" ao Legislativo. ${ }^{40}$

\footnotetext{
37 BENVINDO, Juliano Zaiden. A "última palavra", o poder e a história: O Supremo Tribunal Federal e o discurso de supremacia no constitucionalismo brasileiro. p. 74.

38 TREMBLAY, Luc B. The legitimacy of judicial review: the limits of dialogue between courts and legislatures. p. 630-646.

39 O autor classifica o diálogo em dois subgrupos/modalidades: diálogo como conversação e diálogo como deliberação. Ver TREMBAY, 2005, p. 630 e ss.

40 TREMBLAY, Luc B. The legitimacy of judicial review: the limits of dialogue between courts and legislatures. p. 622.
} 
BRITTO, Melina Carla de Souza; ERZINGER, Fernanda Huss; BARBOSA, Claudia Maria. O diálogo entre poderes e o reequilíbrio institucional: a (in)eficiência do diálogo no combate ao empoderamento judicial. Revista Eletrônica Direito e Política, Programa de Pós-Graduação Stricto Sensu em Ciência Jurídica da UNIVALI, Itajaí, v.16, n.2, $2^{\circ}$ quadrimestre de 2021. Disponível em: www.univali.br/direitoepolitica - ISSN 1980-7791.

Sob esse último aspecto, mesmo sendo a Constituição democraticamente superior à legislação ordinária (e, por esse motivo, o Poder Judiciário tivesse pedigree suficiente para proferir a última palavra, uma vez que seu poder também emana da Constituição e, pelo menos no caso brasileiro, o Judiciário é tido como "guardião" do texto constitucional), isso não quer dizer que necessariamente os juízes e os tribunais devam ter o poder de revisar a legislação. Ainda, na medida em que a legitimidade política é uma questão de genealogia democrática (pedigree), o autor afirma caber ao Legislativo, e não ao Judiciário, o direito moral de tomar as decisões finais com relação à interpretação e à aplicação constitucional $^{41}$ - exatamente porque se constitui em um poder eleito, representativo dos interesses do povo.

Tremblay destaca ainda a análise de Jean Leclair, para quem a teoria do diálogo institucional, como tratada pela Suprema Corte canadense em Vriend v. Alberta (1998) e em R. v. Mills (1999), deveria ser enjeitada, pois se o diálogo pretende tornar cada um dos ramos algo accountable para o outro, pareceria existir uma certa inconsistência com o princípio normativo da separação de poderes, tão necessária à liberdade individual (tal como se pressupunha na sua origem, conforme relatado acima), quanto na atribuição da legitimidade dos Poderes Legislativo e Judiciário. ${ }^{42}$

O diálogo institucional, como modo de legitimação do controle de constitucionalidade, nesse sentido, acabaria por ultrapassar os limites da própria separação de poderes e do sistema de freios e contrapesos.

As objeções da Gargarella aos diáglogos também apontam na direção de dificuldades institucionais e da legitimação democrática. Para ele, um dos principais problemas que podem ser relacionados aos instrumentos "dialógicos" refere-se à sua oclusão à participação protagonista dos cidadãos. Regra geral, o que se vê são processos de tomada de decisão marcados em demasia pela presença de magistrados e executivos hiperativos e poderosos. Há uma

\footnotetext{
41 TREMBLAY, Luc B. The legitimacy of judicial review: the limits of dialogue between courts and legislatures. p. 622.

42 LECLAIR, J. apud TREMBLAY, Luc B. The legitimacy of judicial review: the limits of dialogue between courts and legislatures. P. 629-630.
} 
BRITTO, Melina Carla de Souza; ERZINGER, Fernanda Huss; BARBOSA, Claudia Maria. O diálogo entre poderes e o reequilíbrio institucional: a (in)eficiência do diálogo no combate ao empoderamento judicial. Revista Eletrônica Direito e Política, Programa de Pós-Graduação Stricto Sensu em Ciência Jurídica da UNIVALI, Itajaí, v.16, n.2, $2^{\circ}$ quadrimestre de 2021. Disponível em: www.univali.br/direitoepolitica - ISSN 1980-7791.

apropriação judicial da última palavra institucional. Independentemente do uso do diálogo como forma de reaproximar poderes, para o autor há a necessidade de uma realocação do Legislativo para um lugar de importância tanto quanto o Judiciário, ou seja, de uma recuperação do lugar do povo na política. ${ }^{43}$

Portanto, a noção de sistema constitucional baseado no diálogo democrático e de freios e contrapesos não serve bem e até mesmo dificulta o desenvolvimento de uma prática efetiva do diálogo constitucional. O sistema de freios e contrapesos surgiu para "canalizar a guerra social e política". Ele veio como forma de impedir a mútua opressão entre poderes estatais, de modo que tais objetivos, ainda que valiosos e fundamentais, não se coadunam com a intenção de consolidar uma cultura dialógica. Assevera, ainda, que hoje temos um sistema organizado a partir da "lógica da guerra", que não contribui para desembaraçar a "lógica do diálogo". ${ }^{44}$

Nesse sentido, pode-se dizer que não existe um diálogo democrático onde não há povo, de sorte que, aos que buscam defender o diálogo democrático entre as diferentes esferas do poder, bem como entre elas e a sociedade como um todo (lembrando aqui da ideia de participação popular na tomada de decisões), devem pensar em reformar o sistema de freios e contrapesos ao invés de insistir nesse caminho a fim de avigorar um modelo de diálogo constitucional. ${ }^{45}$

Aliás, se o diálogo entre os poderes, por si só, não é capaz de solucionar o problema da "última palavra", seja ela repassada ao Judiciário ou ao Legislativo, como obstaculizar então o "absolutismo" de um só poder? Se não há que se falar em colaboração, em deliberação conjunta, como destaca Luc B. Tremblay, então como evitar uma possível tirania?

Ao passo que seria correto afirmar que decisões judiciais finais são vinculativas, isto é, unem as partes do processo, de outro não se pode dizer que a "capacidade de dar a última palavra em assuntos constitucionais considerados em uma acepção

\footnotetext{
43 GARGARELLA, Roberto. El nuevo constitucionalismo dialógico frente al sistema de los frenos y contrapesos. p. 149.

${ }^{44}$ GARGARELLA, Roberto. El nuevo constitucionalismo dialógico frente al sistema de los frenos y contrapesos. p. 151.

45 GARGARELLA, Roberto. El nuevo constitucionalismo dialógico frente al sistema de los frenos y contrapesos. p. 152.
} 
BRITTO, Melina Carla de Souza; ERZINGER, Fernanda Huss; BARBOSA, Claudia Maria. O diálogo entre poderes e o reequilíbrio institucional: a (in)eficiência do diálogo no combate ao empoderamento judicial. Revista Eletrônica Direito e Política, Programa de Pós-Graduação Stricto Sensu em Ciência Jurídica da UNIVALI, Itajaí, v.16, n.2, $2^{\circ}$ quadrimestre de 2021. Disponível em: www.univali.br/direitoepolitica - ISSN 1980-7791.

mais ampla" pertença exclusivamente ao Judiciário. ${ }^{46}$ Ou seja, os ramos democraticamente eleitos, muitas vezes, fazem sua vontade prevalecer sobre a decisão judicial - os exemplos são diversos no histórico norte-americano, dentre eles: Brown v. Board of Education of Topeka, 347 U.S. 483 (1954).

De toda forma, o que se pode concluir é que não há como justificar que, se a democracia representa um ganho civilizatório em relação aos modelos aristocráticos, a vontade do Poder Judiciário predomine sobre a vontade manifestada pelos órgãos representativos, os quais estão sujeitos à prestação de contas eleitoral. ${ }^{47}$ É nesse ponto que a teoria dialógica merece ser analisada e debatida, ainda que possua seus aspectos negativos. A teoria merece observância tanto por representar uma tentativa de freio à supremacia judicial quanto por se consubstanciar na discussão acerca do caráter antidemocrático do controle judicial de constitucionalidade.

Em suma, o diálogo institucional quando usado de maneira incorreta pode ser visto como um modo de reinterpretar a relação existente entre Poder Judiciário e Legislativo que, não necessariamente, serve os interesses do povo - razão de ser de uma democracia e essência da motivação da teoria da separação dos poderes. Por outro lado, o diálogo, usado de maneira forma correta, baseada na preocupação de ouvir o povo poderia enriquecer o debate democrático - tornaria, inclusive, o diálogo institucional mais accountable.

\section{A PERSPECTIVA diALÓgICA PRECONIZADA PELA PEC 33/2011 No}

\section{BRASIL}

A Reforma do Judiciário operada pela Emenda Constitucional n. 45, conhecida como e Emenda da Reforma (do Judiciário) apontou na direção da ampliação do controle concentrado de constitucionalidade e em mecanismos que, se de um lado poderiam propiciar segurança e estabilidade jurídica nos julgamentos, de outro

\footnotetext{
${ }^{46}$ SOUZA, Jorge Munhós de. Diálogo Institucional: em algum lugar entre as teorias da supremacia. p. 334.

${ }^{47}$ SOUZA, Jorge Munhós de. Diálogo Institucional: em algum lugar entre as teorias da supremacia. p. 313.
} 
BRITTO, Melina Carla de Souza; ERZINGER, Fernanda Huss; BARBOSA, Claudia Maria. O diálogo entre poderes e o reequilíbrio institucional: a (in)eficiência do diálogo no combate ao empoderamento judicial. Revista Eletrônica Direito e Política, Programa de Pós-Graduação Stricto Sensu em Ciência Jurídica da UNIVALI, Itajaí, v.16, n.2, $2^{\circ}$ quadrimestre de 2021. Disponível em: www.univali.br/direitoepolitica - ISSN 1980-7791.

importariam no fortalecimento do exercício do judicial review, especialmente por parte do Supremo Tribunal federal.

Uma reação ao protagonismo político do STF que evidenciou a disputa de poder entre o Legislativo e o Executivo foi a tramitação e o arquivamento da Proposta de Emenda Constitucional n. 33 de 2011 (PEC 33/2011). Como ressaltou Benvindo na PEC 33/2011 destaca-se o conflito entre Judiciário e Legislativo na demarcação dos limites da atuação de cada um". ${ }^{48}$

Aliás, a fundamentação da própria PEC 33/2011 deu-se no sentido de explicitar a postura de legislador positivo do STF. Seu escopo era demonstrar os riscos dessa atuação do STF, como um superlegislativo, em que não se pudesse prever qualquer possibilidade de controle formal ou institucional de suas decisões. ${ }^{49}$ Propunha dificultar o controle constitucional, reduzindo a abrangência do controle do STF e restringindo seu espaço de poder, mudando a natureza de um dos principais instrumentos de controle e retirar, definitivamente, do STF a primazia político-institucional estribada na última palavra acerca da Constituição. ${ }^{50}$

A polêmica travada em razão da PEC 33/2011 é que justamente em decorrência de buscar conter a supremacia judicial, poderia, segundo seus opositores, ameaçar a independência do Judiciário. A referida Proposta foi objeto de crítica nesse aspecto, sob a alegação de comprometer o regime democrático e o princípio da separação de poderes. ${ }^{51}$

Explica-se. A PEC 33/2011 veiculava três pautas que objetivavam modificar alguns pontos centrais no ordenamento jurídico vigente, no sentido de delimitar o exercício do controle de constitucionalidade pelo Supremo Tribunal Federal. O primeiro tópico merecedor de destaque é a majoração do quórum para que um

\footnotetext{
48 BENVINDO, Juliano Zaiden. A "última palavra", o poder e a história: O Supremo Tribunal Federal e o discurso de supremacia no constitucionalismo brasileiro. p. 77.

${ }^{49}$ FIRMINO, Paulo Augusto Duarte. Do processo de fortalecimento político-institucional do STF à PEC 33/2011: uma discussão necessária. Orientador: Argemiro Moreira Martins. 2016. 213 f. Dissertação (Mestrado em Direito) - Universidade de Brasília, Brasília, 2016. p. 159.

${ }^{50}$ FIRMINO, Paulo Augusto Duarte. Do processo de fortalecimento político-institucional do STF à PEC 33/2011: uma discussão necessária. p. 160.

51 BERCOVICI, Gilberto; LIMA, Martonio Mont'Alverne Barreto. Separação de poderes e a constitucionalidade da PEC 33/2011. Pensar, Fortaleza, v. 18, n. 3, p. 785-801, set./dez. 2013. p. 794.
} 
BRITTO, Melina Carla de Souza; ERZINGER, Fernanda Huss; BARBOSA, Claudia Maria. O diálogo entre poderes e o reequilíbrio institucional: a (in)eficiência do diálogo no combate ao empoderamento judicial. Revista Eletrônica Direito e Política, Programa de Pós-Graduação Stricto Sensu em Ciência Jurídica da UNIVALI, Itajaí, v.16, n.2, $2^{\circ}$ quadrimestre de 2021. Disponível em: www.univali.br/direitoepolitica - ISSN 1980-7791.

tribunal ou seus órgãos especiais, em sede de controle difuso, ou seja, pela via recursal e via de regra na análise de um caso concreto, pudesse modificar o entendimento sobre a constitucionalidade de uma lei. Desde o ponto de vista dos apoiadores da PEC, as leis gozam da presunção de constitucionalidade e, mesmo que essa seja relativa, modificar a lei, para que se possa reverter essa presunção e declarar a inconstitucionalidade de uma lei, deveria ser exigida das Cortes um entendimento mais sólido do que o expresso do que a maioria simples então exigida. Os opositores da PEC, em contrapartida, argumentavam que esse quórum visava dificultar a mudança do entendimento sobre a constitucionalidade da lei pelo judiciário, o que afetaria sua independência em por via de consequência, a separação de poderes, cláusula pétrea da Constituição brasileira.

O segundo item de mudança trazido pela PEC 33/2011 tratava da súmula vinculante. O texto sugerido ampliava o quórum para sua edição e condicionaria a súmula à aprovação do Legislativo, instituindo um controle direto deste Poder, a fim de obstar eventuais arbitrariedades do Judiciário. ${ }^{52}$

O terceiro enfoque, por sua vez, está relacionado ao controle de emendas constitucionais. A proposta era que fosse vedado ao STF a suspensão da eficácia de emenda constitucional por medida cautelar. Além disso, oportunizar ao Legislativo a interferência no controle de constitucionalidade realizado pela Corte Suprema, cabendo ao primeiro decidir quando se tratar de declaração de inconstitucionalidade de emendas constitucionais, abrindo-se, inclusive, a possibilidade de realização de consulta popular em caso de manifestação contrária do Congresso Nacional à decisão judicial do STF a fim de dirimir a controvérsia. ${ }^{53}$

A PEC 33/2011chegou a ser aprovada na Comissão de Constituição e Justiça e de Cidadania ( $C \mathrm{CJC})$, tendo, de início, franca adesão parlamentar, embora alguns partidos de oposição tenham se manifestado contrariamente à discussão. O STF contestou tal anuência e reagiu, contrariamente, de diversas formas. A primeira foi com a proposta da Medida de Segurança n. 32.033, pelo Ministro Gilmar

52 FIRMINO, Paulo Augusto Duarte. Do processo de fortalecimento político-institucional do STF à PEC 33/2011: uma discussão necessária. p. 160-161.

53 FIRMINO, Paulo Augusto Duarte. Do processo de fortalecimento político-institucional do STF à PEC 33/2011: uma discussão necessária. p. 161. 
BRITTO, Melina Carla de Souza; ERZINGER, Fernanda Huss; BARBOSA, Claudia Maria. O diálogo entre poderes e o reequilíbrio institucional: a (in)eficiência do diálogo no combate ao empoderamento judicial. Revista Eletrônica Direito e Política, Programa de Pós-Graduação Stricto Sensu em Ciência Jurídica da UNIVALI, Itajaí, v.16, n.2, $2^{\circ}$ quadrimestre de 2021. Disponível em: www.univali.br/direitoepolitica - ISSN 1980-7791.

Mendes, contra a tramitação e a deliberação do Projeto de Lei n. 4.470/2012 do Senado Federal. A decisão monocrática do Ministro interferiu diretamente em matéria político-partidária do Legislativo. Não obstante, tal Medida de Segurança acabou sendo cassada pelo próprio STF, de modo que o Projeto de Lei $n$. 4.470/2012 foi convertido na Lei n. 12.875/2013. Se não bastasse, pouco tempo depois, no julgamento da ADI 5105, o STF fez prevalecer sua orientação em face do Legislativo a respeito da mesma matéria. ${ }^{54}$

Além disso, existiram várias insurgências por meio da imprensa a fim de impedir o êxito da PEC. Houve, inclusive, decisão em Mandado de Segurança (n. 32.036) ordenando que a Câmara de Deputados apresentasse justificativa a respeito da PEC. ${ }^{5}$ De modo que, em 31 de janeiro de 2015, o Presidente da Câmara se comprometeu a não instalar comissão especial para que se procedesse o prosseguimento da PEC, acarretando o seu arquivamento no Legislativo. ${ }^{56}$

O que restou evidente no cenário que envolveu a PEC 33/2011 é que qualquer tentativa de imposição de limites ao Judiciário, com a criação de um poder deliberativo final mediante a participação dos representantes eleitos e da sociedade, buscando reestabelecer o equilíbrio democrático, é motivo de forte oposição, seja pelo STF, ${ }^{57}$ seja pelo Judiciário de maneira geral. Ademais, embora a PEC tenha apontado um problema e oferecido um caminho, qual seja, a imposição de limites mínimos e necessário ao STF, é importante notar que ela não tocou todos os pontos relativos à judicialização da política e do ativismo judicial. ${ }^{58}$

São muitas as críticas que se pode estabelecer, seja a favor ou contra a tramitação da referida PEC. Nesse sentido, Cláudio Ladeira de Oliveira afirma que "o discurso de primazia do Judiciário não é senão um bordão que explica os anseios

54 FIRMINO, Paulo Augusto Duarte. Do processo de fortalecimento político-institucional do STF à PEC 33/2011: uma discussão necessária. p. 162-163.

55 FIRMINO, Paulo Augusto Duarte. Do processo de fortalecimento político-institucional do STF à PEC 33/2011: uma discussão necessária. p. 162-163.

56 FIRMINO, Paulo Augusto Duarte. Do processo de fortalecimento político-institucional do STF à PEC 33/2011: uma discussão necessária. p. 163.

57 FIRMINO, Paulo Augusto Duarte. Do processo de fortalecimento político-institucional do STF à PEC 33/2011: uma discussão necessária. p. 163.

58 FIRMINO, Paulo Augusto Duarte. Do processo de fortalecimento político-institucional do STF à PEC 33/2011: uma discussão necessária. p. 169. 
BRITTO, Melina Carla de Souza; ERZINGER, Fernanda Huss; BARBOSA, Claudia Maria. O diálogo entre poderes e o reequilíbrio institucional: a (in)eficiência do diálogo no combate ao empoderamento judicial. Revista Eletrônica Direito e Política, Programa de Pós-Graduação Stricto Sensu em Ciência Jurídica da UNIVALI, Itajaí, v.16, n.2, $2^{\circ}$ quadrimestre de 2021. Disponível em: www.univali.br/direitoepolitica - ISSN 1980-7791.

aristocráticos de parte dos profissionais do ramo, o de viver numa 'juristocracia': o governo dos juízes, pelos juízes, para os juízes". ${ }^{59}$

Para Juliano Zaiden Benvindo, a PEC 33/2011 evidencia o conflito, o desacordo político, sendo a última palavra pertencente ao Judiciário. Ele desconstrói as ideias de que "não há conflito, mas um diálogo harmônico entre os poderes" e que o "desacordo político sobre direitos é mais bem resolvido pelo Judiciário, sobretudo diante de suas capacidades técnicas e propósito de defesa de minorias". Da mesma forma, desfaz a noção de que "a última palavra é do Judiciário e qualquer tentativa de se interpretar diferentemente ferirá os mais basilares princípios do constitucionalismo democrático". 60

A ideia trazida, ao analisar a PEC 33/2011, é demonstrar necessariamente que a harmonia entre os poderes é problemática e pouco sustentável, que "muito mais do que diálogo e harmonia, há, sem dúvida, uma disputa por poder, que se consubstancia em termos discursivos próprios". 61

O que se observa é um Judiciário que reage a uma proposta parlamentar que restringiria parcialmente seus poderes e que usa de estratégias de persuasão pública para gizar o que se espera de uma democracia constitucional, na qual o Judiciário é o seu defensor contra possíveis riscos de um retrocesso autoritário papel de defensor libertário do Poder Judiciário versus "papel retaliativo, político e interessado do parlamento". ${ }^{62}$

59 OLIVEIRA, Cláudio Ladeira de. PEC 33, separação de poderes e o aprisionamento judicial da Constituição, 2013. Disponível em: <https://paginadoenock.com.br/claudio-ladeira-de-oliveirapec-33-separacao-de-poderes-e-o-aprisionamento-judicial-da-constituicao/>. Acesso em: 18 jul. 2018.

60 BENVINDO, Juliano Zaiden. A "última palavra", o poder e a história: O Supremo Tribunal Federal e o discurso de supremacia no constitucionalismo brasileiro. p. 80.

61 BENVINDO, Juliano Zaiden. A "última palavra", o poder e a história: O Supremo Tribunal Federal e o discurso de supremacia no constitucionalismo brasileiro. p. 81.

62 BENVINDO, Juliano Zaiden. A "última palavra", o poder e a história: O Supremo Tribunal Federal e o discurso de supremacia no constitucionalismo brasileiro. p. 81. 
BRITTO, Melina Carla de Souza; ERZINGER, Fernanda Huss; BARBOSA, Claudia Maria. O diálogo entre poderes e o reequilíbrio institucional: a (in)eficiência do diálogo no combate ao empoderamento judicial. Revista Eletrônica Direito e Política, Programa de Pós-Graduação Stricto Sensu em Ciência Jurídica da UNIVALI, Itajaí, v.16, n.2, $2^{\circ}$ quadrimestre de 2021. Disponível em: www.univali.br/direitoepolitica - ISSN 1980-7791.

\section{CONSIDERAÇÕES FINAIS}

A partir das discussões elencadas neste artigo, conclui-se que, ao passo que o diálogo institucional encontra diversas formas de incorporação ao sistema democrático, ele não constitui-se como uma finalidade específica de nenhum dos poderes e, de resto, não é uma preocupação central na teoria da tripartição de poderes, mas poderia ser utilizado como forma de assegurar uma atuação colaborativa entre os poderes e limitar a atuação eventualmente abusiva do Judiciário. O problema justamente é que, na prática, o exercício do diálogo de forma equânime, cooperativa e recíproca não se mostra possível. Ele se transforma, na verdade, em uma disputa por poder entre as instituições estatais.

Ademais, o diálogo institucional não necessariamente soluciona a problemática acerca da supremacia judicial e o fato de que o Poder Judiciário, por intermédio do controle de constitucionalidade, possa fazer prevalecer os seus interesses quando há controvérsias políticas, sociais e econômicas. O diálogo também não é, infalivelmente, a chave para a devolução do poder último, máximo, ao povo (aqui entendido como povo, propriamente dito, ou seus representantes).

Constata-se, ainda, a existência de argumentos a favor e contrários ao diálogo institucional: enquanto por um lado ele pode servir para combater a supremacia judicial e o sufocamento dos demais poderes, por outro, percebe-se que o que the falta é a eficiência no diálogo aberto e entre iguais, bem como a participação popular, em prol da democracia e do constitucionalismo.

\section{REFERÊNCIAS DAS FONTES CITADAS}

BARBOSA, Claudia Maria. Algunos aspectos de la independencia judicial en Brasil. In: Independencia judicial en América Latina: ¿De quien, para que, como¿. Bogota: Ilsa, 2004, p. 417-437.

BATEUP, Christine A. The Dialogue Promise: Assessing the Normative Potential of Theories of Constitutional Dialogue. Brooklyn Law Review, v. 71, 2006.

BENVINDO, Juliano Zaiden. A "última palavra", o poder e a história: O Supremo Tribunal Federal e o discurso de supremacia no constitucionalismo brasileiro. 
BRITTO, Melina Carla de Souza; ERZINGER, Fernanda Huss; BARBOSA, Claudia Maria. O diálogo entre poderes e o reequilíbrio institucional: a (in)eficiência do diálogo no combate ao empoderamento judicial. Revista Eletrônica Direito e Política, Programa de Pós-Graduação Stricto Sensu em Ciência Jurídica da UNIVALI, Itajaí, v.16, n.2, $2^{\circ}$ quadrimestre de 2021. Disponível em: www.univali.br/direitoepolitica - ISSN 1980-7791.

Revista de Informação Legislativa, ano 51, n. 201, p. 71-95, jan./mar. 2014.

BERCOVICI, Gilberto; LIMA, Martonio Mont'Alverne Barreto. Separação de poderes e a constitucionalidade da PEC 33/2011. Pensar, Fortaleza, v. 18, n. 3, p. 785-801, set./dez. 2013.

BILLINGSLEY, Barbara. Listening to the Dialogue: An Examination of the Degree of Public and Media Attention Provided to the Legislative Responses to Court Decisions Involving Equality Rights and Sexual Orientation. Dialogues about Justice: The Public, Legislators, Courts and the Media. October, Hull, QC, 2002. Disponível em: <https://ciaj-icaj.ca/wpcontent/uploads/2016/05/billingsleybarb_27-60.pdf>. Acesso em: 13 jul. 2018.

BRASIL. Constituição da República Federativa do Brasil, de 05 de outubro de 1988. Disponível em:

<http://www.planalto.gov.br/ccivil_03/Constituicao/ConstituicaoCompilado.htm> . Acesso em: 29 ago. 2019.

FIRMINO, Paulo Augusto Duarte. Do processo de fortalecimento políticoinstitucional do STF à PEC 33/2011: uma discussão necessária. Orientador: Argemiro Moreira Martins. 2016. 213 f. Dissertação (Mestrado em Direito) Universidade de Brasília, Brasília, 2016.

FONSECA, Claudia de Oliveira. O ativismo judicial e a supremacia legislativa no contexto dos diálogos institucionais. Caderno de Ciências Sociais Aplicadas, Vitória da Conquista, n. 15, p. 35-57, jul./dez. 2013.

GARGARELLA, Roberto. El nuevo constitucionalismo dialógico frente al sistema de los frenos y contrapesos. In: GARGARELLA, Roberto (Comp.). Por una justicia dialógica: El Poder Judicial como promotor de la deliberación democrática. $1^{a}$ ed. Buenos Aires: Siglo Veintiuno Editores, 2014.

HOGG, Peter W.; BUSHELL, Allison A. El diálogo de la Carta entre los tribunales y las legislaturas. Revista Argentina de Teoría Jurídica, Universidad Torcuato di Tella, Escuela de Derecho, v. 14, p. 75-118, dez. 2013. Disponível em:

<https://www.utdt.edu/ver_contenido.php?id_contenido=9173\&id_item_menu= 5858>. Acesso em: 24 jun. 2018.

LECLAIR, Jean. La métaphore du dialogue en droit constitutionnel canadien: un concept qui dessert les intérêts du citoyen?. Dialogues about Justice: The Public, Legislators, Courts and the Media. October, Hull, QC, 2002. Disponível em: <https://ciaj-icaj.ca/wpcontent/uploads/documents/2016/09/625.pdf?id=7925\&1531924967>. Acesso em: 18 jul. 2018.

MACHADO, Donisete Edinilson. Ativismo judicial: limites institucionais democráticos e constitucionais. São Paulo: Letras Jurídicas, 2011. 
BRITTO, Melina Carla de Souza; ERZINGER, Fernanda Huss; BARBOSA, Claudia Maria. O diálogo entre poderes e o reequilíbrio institucional: a (in)eficiência do diálogo no combate ao empoderamento judicial. Revista Eletrônica Direito e Política, Programa de Pós-Graduação Stricto Sensu em Ciência Jurídica da UNIVALI, Itajaí, v.16, n.2, $2^{\circ}$ quadrimestre de 2021. Disponível em: www.univali.br/direitoepolitica - ISSN 1980-7791.

MADISON, James. Exame e explicação do princípio da separação dos poderes. In: HAMILTON, Alexander; JAY, John; MADISON, James. O Federalista. Trad. de Hiltomar Martins Oliveira. Belo Horizonte: Líder, 2003.

MAIA, Maurilio Casas. A separação de poderes no Brasil hoje. Revista de Direito Constitucional e Internacional, v. 25, n. 104, p. 15-36, nov./dez. 2017.

MONTESQUIEU. O Espírito das Leis. $6^{\mathrm{a}}$ ed. Trad. de Pedro Vieira Mota. São Paulo: Saraiva, 1999. Disponível em: <http://egov.ufsc.br/portal/conteudo/oesp\%C3\%ADrito-das-leis>. Acesso em: 11 jul. 2018.

OLIVEIRA, Cláudio Ladeira de. PEC 33, separação de poderes e o aprisionamento judicial da Constituição, 2013. Disponível em:

$<$ https://paginadoenock.com.br/claudio-ladeira-de-oliveira-pec-33-separacaode-poderes-e-o-aprisionamento-judicial-da-constituicao/>. Acesso em: 18 jul. 2018.

OLIVEIRA, Leonardo Alves de. Ativismo judicial: qual o limite do Poder Judiciário? Revista Bonijuris, v. 29, n. 641, p. 24-28, abr. 2017.

PAULA, Alexandre Sturion de. Ativismo judicial no processo civil: limites e possibilidades constitucionais. Campinas: Servanda, 2012.

SILVA, Eduardo Fernandes da. Excesso de jurisdição ou escassez de política: apontamentos sobre a jurisdição constitucional brasileira à luz da evolução histórica do estado democrático de direito. Revista da Faculdade de Direito da UFMG, n. 62, p. 209-230, jan./jun. 2013.

SILVA, José Afonso da. Comentário contextual à Constituição. $9^{a}$ ed. São Paulo: Malheiros, 2014.

SILVA, José Afonso da. Curso de Direito Constitucional Positivo. São Paulo: Malheiros, 2005.

SOUZA, Jorge Munhós de. Diálogo Institucional: em algum lugar entre as teorias da supremacia. In: FELLET, André Luiz Fernandes; NOVELINO, Marcelo; PAULA, Daniel Giotti de (Orgs.). As novas faces do ativismo judicial. $2^{\mathrm{a}}$ ed. Bahia: Editora Juspodivm, 2013.

TREMBLAY, Luc B. The legitimacy of judicial review: the limits of dialogue between courts and legislatures. Oxford University Press and New York

University School of Law, I-CON, v. 3, n. 4, p. 617-648, 2005. Disponível em: <https://watermark. silverchair.com/moi042.pdf?token=AQECAHi208BE49Ooan9 kkhW_Ercy7Dm3ZL_9Cf3qfKAc485ysgAAAZ0wggGZBgkqhkiG9w0BBwagggGKMII BhgIBADCCAX8GCSqGSIb3DQEHATAeBglghkgBZQMEAS4wEQQM44sNxfQzjHhX2 X3-

AgEQgIIBUEbEQBgLA74McxAeUIKLBOXmxcECrLflBkYaponndRPhbP_GPWZDD3L8s tKye5q1E5gTb-2iXpkQILMTP8pTv7e-xaIxhFjPdtKflHiOd-

DPDr85mdYKnYgxfYILohXP74BgPQf7hpUWufNyqRndyf1sc_PuyRZxv7scIpe1AGF2i 
BRITTO, Melina Carla de Souza; ERZINGER, Fernanda Huss; BARBOSA, Claudia Maria. O diálogo entre poderes e o reequilíbrio institucional: a (in)eficiência do diálogo no combate ao empoderamento judicial. Revista Eletrônica Direito e Política, Programa de Pós-Graduação Stricto Sensu em Ciência Jurídica da UNIVALI, Itajaí, v.16, n.2, $2^{\circ}$ quadrimestre de 2021. Disponível em: www.univali.br/direitoepolitica - ISSN 1980-7791.

1Q42cHk2BXXnavTwzJHrRSoTEeqY0HQKWQJrmo7pECjf9oTtS8-mv22CtiMs9NosYB0iJ7Ob8PIIr_SNTwz-0MtePcoi1tN7QP98EGkg5SRZhxHv7ZqHGpT24MgRIfL8aqpdP4HNAJY8SCA1 yeoLx3Hqvc5TAePa6nHJlejkta7LrXflvYyW 8EVBWf4LKFEdQzHIGPWwT9oNGVrQMYhMIsss]-hiMO5GAQ25kzBcR-

ON52rfXmCxhvCAfL3EsI4IQxmUcJqGYDnOP_OIMA>. Acesso em: 30 jul. 2018.

RECEBIDO EM: JUN/2019

APROVADO EM: JUL/2021 